\title{
Electrophoretic Deposition of Titanium Oxide Nanoparticle Films for Dye-Sensitized Solar Cell Applications
}

\author{
Jason Bandy, Qifeng Zhang, Guozhong Cao* \\ Department of Materials Science and Engineering, University of Washington, Seattle, USA. \\ Email: "gzcao@u.washington.edu
}

Received July $6^{\text {th }}, 2011$; revised August $5^{\text {th }}, 2011$; accepted August $30^{\text {th }}, 2011$.

\begin{abstract}
Films of titanium oxide nanocrystalline particles (P25) were deposited using an electrophoretic deposition. The film's characteristics were tuned for applications in dye-sensitized solar cells. Electrophoretic deposition allows control of film characteristics such as porosity and thickness by changing deposition parameters, such as the electric field and deposition time. To increase the efficiency of the dye-sensitized solar cells with films created using electrophoretic deposition, the problem of an electrolyte contamination in the film, which occurred during deposition, was addressed. With the proper chemical post treatment, efficiency of $2.93 \%$ with fill factor of 0.55 was obtained when the films were annealed at $450^{\circ} \mathrm{C}$. A low annealing temperature of $150^{\circ} \mathrm{C}$ resulted in efficiencys of $1.99 \%$ with fill factor of 0.68 . When the P25 was replaced by hydrothermally fabricated titanium oxide nanocrystalline particles, efficiency of $4.91 \%$ with fill factor of 0.55 was obtained.
\end{abstract}

Keywords: Dye-Sensitized Solar Cells, Electrophoretic Deposition, $\mathrm{TiO}_{2}$ Nanoparticles

\section{Introduction}

Since dye-sensitized solar cells (DSCs) were first created by O'Regan and Gratzel to convert sunlight into electrical energy [1], there has been much innovation in this emerging technology from creating dyes which absorb a longer range of wavelengths to better quality titanium oxide nanocrystalline particles [2-8], which are much more advantageous in crystal structure when compared to the commercial brand of titanium oxide nanocrystalline particles, so-called P25 (Degussa AG, Germany). More recently, there have been many research endeavors towards creating flexible DSCs, where flexible transparent plastics coated with a transparent conductive oxide are used [9-13]. Flexibles DSCs offer a technological advantage since they are not fragile compared to traditional DSCs and have a versatile shape. Generally a post treatment at elevated temperatures is used when sol-gel methods are employed to crystallize the titanium oxide nanoparticle film $[14,15]$; however, this high temperature anneal cannot be used when flexible substrates are used as this leads to degradation of the substrate and loss of transparency.
Electrophoretic deposition (EPD) is an electrochemical deposition of charged particles with an applied electric field in a suspension containing the particles, electrolyte, additives, and solvent $[16,17]$. It is a two-step process, including charging of the particles in the suspension and drifting of the charged particles towards an electrode. Additives such as water to the electrolyte can be added to allow control of the packing density of the particles with a change in current. Yum et al. pointed out the hydrogen gas from the electrolysis of water at the cathode could interrupt the deposition of nanoparticles resulting in a lower packing density [18]. Therefore, the packing density was suggested to be related to the current. This gives merits to the EPD method as this allows deposition of particles into films with tunable characteristics that are very reproducible. Film characteristics such as morphology and thickness can be altered by changing the EPD conditions such as voltage, deposition time, and electrolyte concentration. In addition, since the nanoparticles deposited can be nanocrystalline, only a low temperature post thermal treatment of for example, $100^{\circ} \mathrm{C}$ to $150^{\circ} \mathrm{C}$ is required to evaporate the solvent.

In this investigation, problems of electrolyte contami- 
nation associated with EPD of nanocrystalline titanium oxide particles were studied. By using a proper chemical post treatment to remove the electrolyte, much higher efficiencies can be obtained on the films composed of commercial P25 nanoparticles. Even higher efficiencies were achieved with the use of hydrothermally grown nanocrystalline titanium oxide particles.

\section{Experimental Details}

Glass coated with Fluorine doped Tin Oxide (FTO) was used as the substrate for creating the photoelectrode film of dye-sensitized solar cells with an active area of 36 $\mathrm{mm}^{2}$. A dispersion of nanocrystalline titanium oxide particles (P25, $20 \mathrm{~nm}$, Deguessa) with concentration of 0.25 $\mathrm{g} / \mathrm{L}$ in isopropyl alcohol (IPA, 99.5\%, Mallinckrodt) was used where $5 \times 10^{-5} \mathrm{M}$ magnesium nitrate hexahydrate (Aldrich, $99.995+\%$ ) and $2 \mathrm{vol} \%$ deionized water (DI water) were used as the electrolyte during the EPD process. A standard spacing of $2 \mathrm{~cm}$ was used between the FTO cathode and platinum anode. These conditions were similarly used by Yum et al. [18]. Nanocrystalline titanium oxide particle films were also created using a doctor blading method for comparison.

Various applied electric fields and deposition times were adopted to determine optimum conditions for creating nanocrystalline titanium oxide particle films for DSCs. Scanning Electron Microscopy (SEM) was employed to characterize the structure and morphology of the films. Cross-sections of the films were also viewed with the SEM to obtain thicknesses of the films so as to determine the optimum deposition time. In addition, energy dispersive X-ray (EDX) analysis was performed on the films to determine the extent of the electrolyte contamination in the films.

Soaking treatments after deposition were used to remove magnesium electrolyte contamination from the nanocrystalline titanium oxide particle films. Solutions of $0.1 \mathrm{~N} \mathrm{H}_{2} \mathrm{SO}_{4}$ in DI water and $0.1 \mathrm{~N} \mathrm{H}_{2} \mathrm{SO}_{4}$ in IPA was prepared. Film samples were immersed in the $0.1 \mathrm{~N}$ $\mathrm{H}_{2} \mathrm{SO}_{4}$ in DI water solution for 1 hour before and after annealing and immersed in the $0.1 \mathrm{~N} \mathrm{H}_{2} \mathrm{SO}_{4}$ in IPA for 1 hour and 12 hours. The $0.1 \mathrm{~N} \mathrm{H}_{2} \mathrm{SO}_{4}$ in DI water treatments were followed by 15 minute immersions in pure DI water and the $0.1 \mathrm{~N} \mathrm{H}_{2} \mathrm{SO}_{4}$ in IPA were followed by 15 minute immersions in pure IPA to remove excess $\mathrm{H}_{2} \mathrm{SO}_{4}$.

Post thermal treatments of $450^{\circ} \mathrm{C}$ were carried out on the sample prior to dye adsorption. Immediately after completion of the thermal treatments, the titanium oxide nanocrystalline films were soaked in N719 dye for 24 hours.

Once the optimum post treatment was discovered, films created using low temperature annealing of $150^{\circ} \mathrm{C}$ were dyed and tested using the same procedure as the other samples.

The optimum post treatment was also used in the creation of films with hydrothermally grown nanocrystalline titanium oxide particles, which were annealed at $450^{\circ} \mathrm{C}$ as well.

The solar cell performances were characterized while the samples were irradiated with AM 1.5 simulated sunlight with the power density of $100 \mathrm{~mW} / \mathrm{cm}$. The electrolyte was composed of $0.6 \mathrm{M}$ tetrabutylammonium iodide, $0.1 \mathrm{M}$ lithium iodide, $0.1 \mathrm{M}$ iodine, and $0.5 \mathrm{M}$ 4-tert-butylpyridine in acetonitrile. A platinum coated FTO glass was used as the counter electrode.

\section{Results and Discussion}

Using varying electric field intensities, different film morphologies were observed. As the electric field was increased, the film morphology became much denser. This is in agreement with previously published data [18]. A rise in the electric field is met with an increase in the packing density of the film and a decrease in the EPD current, but the packing density is actually dependent on the EPD current as there is electrolysis of water at the cathode. A higher current results in more hydrolysis of water resulting in more evolution of hydrogen gas. The hydrogen gas evolution interrupts the deposition of the nanocrystalline titanium oxide particle and creates pores in the film. It was important to find a balance between internal surface area of the film and the ability of the dye to penetrate deep into the films pores. Too porous of a film results in low surface area and poor light absorption, while too dense of a film results in low penetration of the dye. From the SEM images in Figure 1, it was found 20 $\mathrm{V} / \mathrm{cm}$ gave the desired film morphology. Cross-sectional views of the nanocrystalline titanium oxide particle films revealed the desired deposition time to be 15 minutes, leading to a film thickness of $16 \mu \mathrm{m}$ as shown in Figure 2.

Shane et al. showed how the magnesium nitrate contaminated the film [3]. As the magnesium nitrate ions approach the cathode, the electrolysis of water causes the reactions shown in Equations (1) and (2) [19].

$$
\begin{gathered}
2 \mathrm{H}_{2} \mathrm{O}+2 \mathrm{e}^{-}=\mathrm{H}_{2}(\mathrm{~g})+2 \mathrm{OH}^{-} \\
\mathrm{MgNO}_{3}{ }^{+}+2 \mathrm{OH}^{-}=\mathrm{Mg}(\mathrm{OH})_{2(\mathrm{~s})}+\mathrm{NO}_{3}^{-}
\end{gathered}
$$

The electrolysis of the water not only produces hydrogen gas, but hydroxyl ions as well. These ions react with the magnesium nitrate ions creating a magnesium hydroxide solid where the film is depositing [19].

EDX microanalysis of the films as shown in Figure 3 revealed a high concentration of $\mathrm{Mg}$ in the titanium oxide nanocrystalline particle films. Our experiments also showed when a film of $\mathrm{MgO}$ particles was created using a doctor blading technique and soaked in the N719 dye 


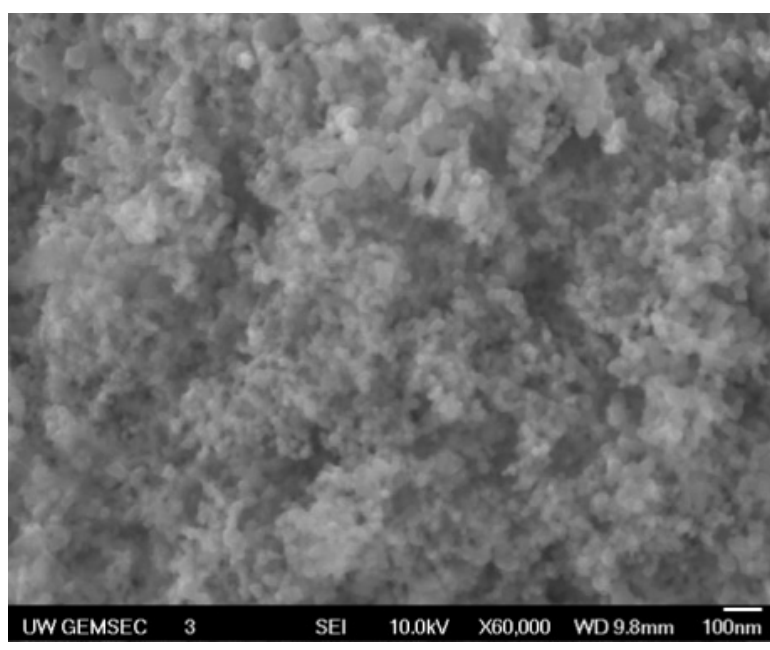

(a)

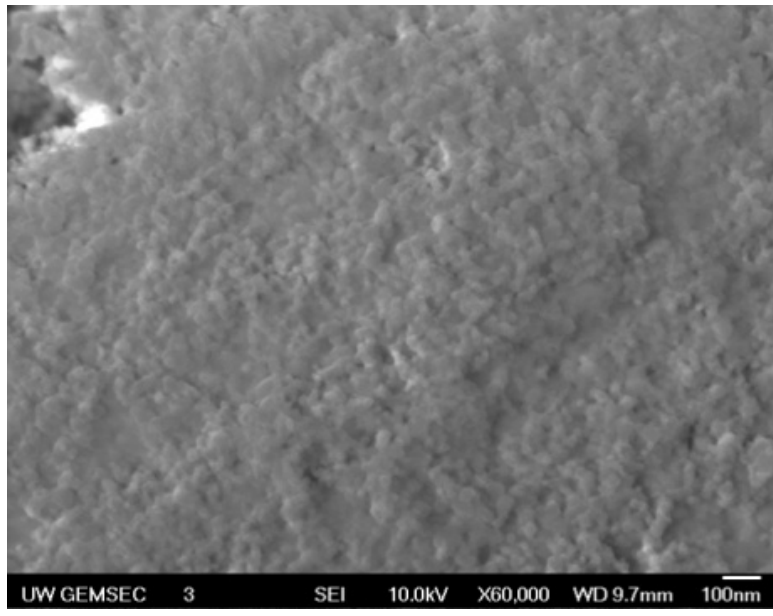

(c)

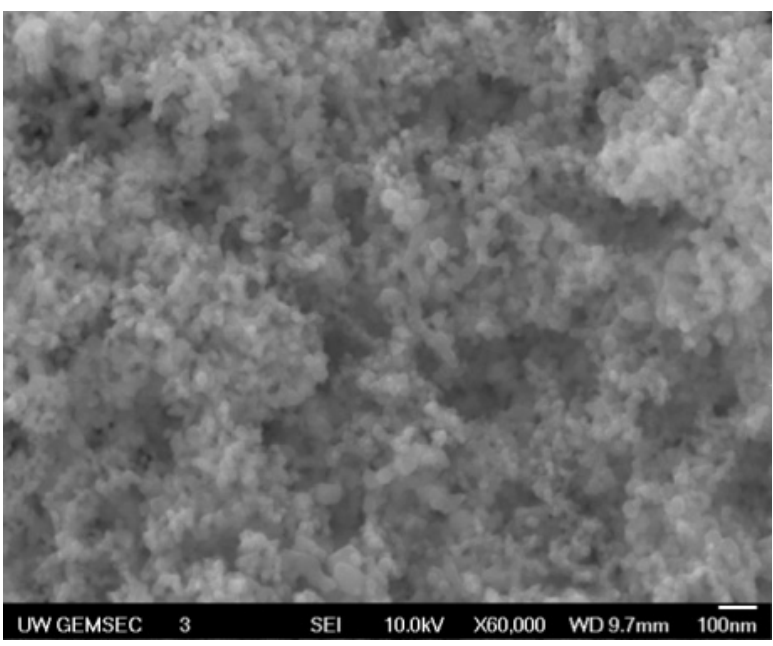

(b)

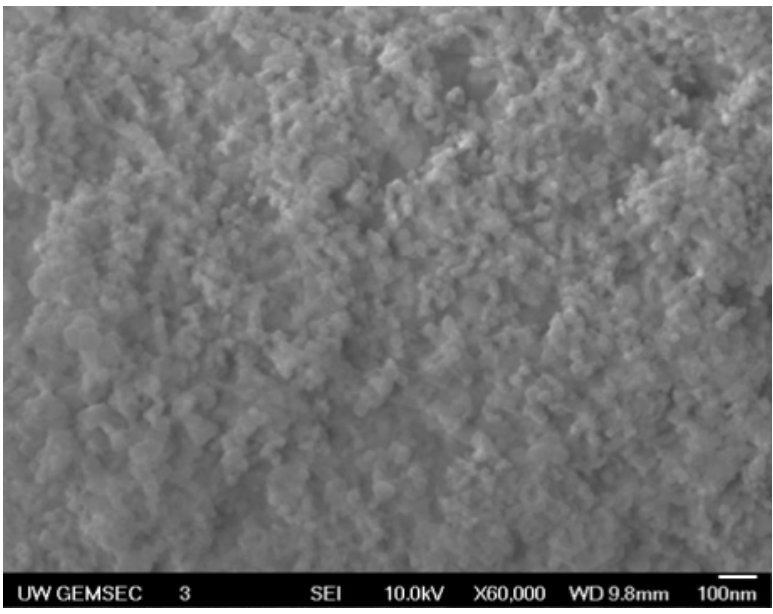

(d)

Figure 1. SEM images of deposited films with EPD using electric fields of (a) $15 \mathrm{~V} / \mathrm{cm}$; (b) $20 \mathrm{~V} / \mathrm{cm}$; (c) $25 \mathrm{~V} / \mathrm{cm}$; and (d) 30 $\mathrm{V} / \mathbf{c m}$.

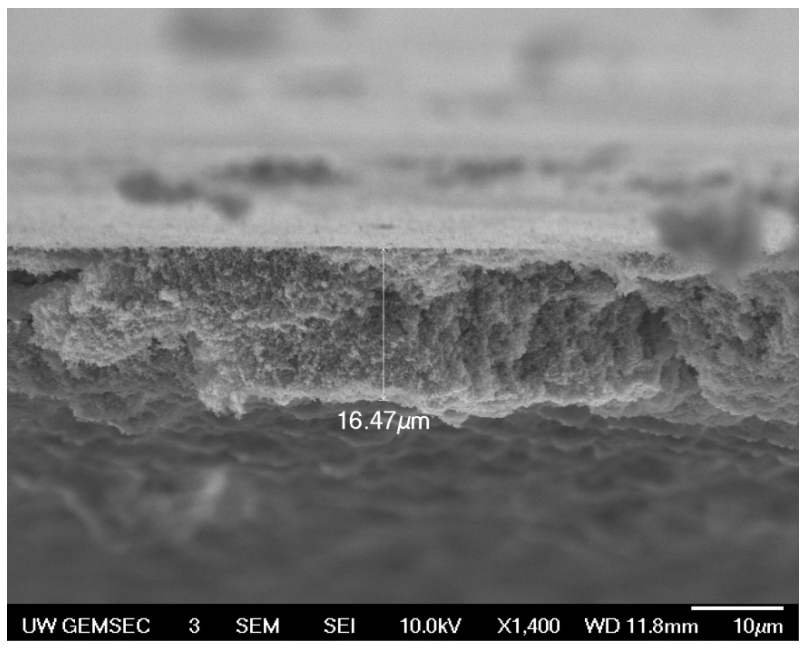

Figure 2. Cross-sectional SEM image of the nanocrystalline titanium oxide particle film with a deposition time of $15 \mathrm{~min}$.

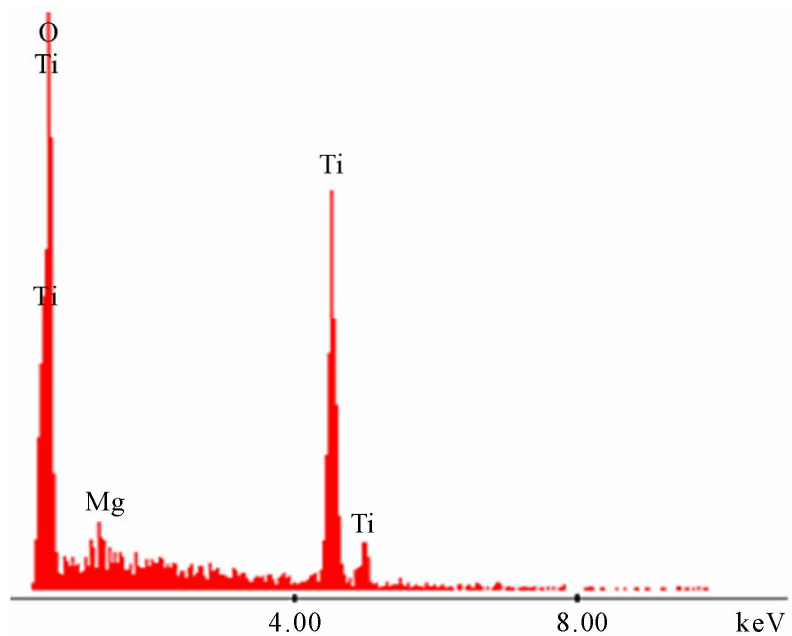

Figure 3. EDX spectrum of titanium oxide nanocrystalline particle films prepared using EPD. 
for 24 hours, it was found the dye did not adhere to the $\mathrm{MgO}$ particles like it normally would to the titanium oxide nanocrystalline particles. The magnesium hydroxide contamination in the titanium oxide nanocrystalline particle film oxidizes during the annealing process preventing adhesion of the dye to the nanocrystalline titanium oxide particle film during dye-sensitization. This resulted in very low short circuit currents and energy conversion efficiencies.

The use of post treatments for washing the as-deposited films resulted in varying levels of success as can be seen in Table 1. No post treatment resulted in poorer efficiencies. The use of $1 \mathrm{~h} 0.1 \mathrm{~N} \mathrm{H}_{2} \mathrm{SO}_{4} \mathrm{H}_{2} \mathrm{O}$ Immersion followed by 15 min $\mathrm{H}_{2} \mathrm{O}$ immersion resulted in much better energy conversion efficiencies; however, there was a noticeable decrease in the thickness of the film after immersion. Corresponding energy conversion efficiencies were sporadic with a standard deviation of 0.55 . IPA post treatments resulted in less reduction of the film thickness, but required more time to remove the contamination. $1 \mathrm{~h} 0.1 \mathrm{~N} \mathrm{H}_{2} \mathrm{SO}_{4}$ IPA immersion followed by 15 min pure IPA immersion resulted in poor energy conversion efficiencies since it was unable to remove the contamination. From the color of the film, the dye did not successfully adhere to the nanocrystalline titanium oxide particles. 15 h $0.1 \mathrm{~N} \mathrm{H}_{2} \mathrm{SO}_{4}$ IPA immersion followed by 15 min pure IPA immersion provided the best results, which matched the $2.94 \%$ efficiency of a DSC whose titanium oxide nanoparticle film was created using a doctor blading technique. The energy conversion efficiencies were also very reproducible with a standard deviation of 0.054 .

$15 \mathrm{~h} 0.1 \mathrm{~N} \mathrm{H}_{2} \mathrm{SO}_{4}$ IPA immersion followed by $15 \mathrm{~min}$ pure IPA immersion post treatment was used in the creation of a titanium oxide nanocrystalline particle film which had undergone a low temperature anneal of $150^{\circ} \mathrm{C}$. Efficiencies of $1.99 \%$ with fill factors (FFs) of 0.68 were obtained.
The same optimum post treatment was also used to purify films created with hydrothermally fabricated nanoparticles. Efficiencies of $4.91 \%$ with fill factors of 0.55 were obtained.

\section{Conclusions}

Electrophoretic deposition allows good control of porosity by varying the electric field intensity and thus the current. An increase in current leads to more evolution of hydrogen gas creating more porosity in the film. The film thickness is also tunable by varying the deposition time.

Magnesium ions can be employed to attach on P25 $\left(\mathrm{TiO}_{2}\right)$ nanoparticles for electrophoretic deposition of $\mathrm{TiO}_{2}$ thin film for dye-sensitized solar cell application. However, the residual of magnesium ions, which are in the formation of magnesium oxide after the thermal treatment, prevents the adhesion of dye to the $\mathrm{TiO}_{2}$ nanoparticles. It was found a suitable chemical post treatment might effectively remove the magnesium oxide from the $\mathrm{TiO}_{2}$ thin film, leading to a significant efficiency increase from $1.99 \%$ to $3.27 \%$. The maximum efficiency of $4.91 \%$ was achieved with hydrothermally grown $\mathrm{TiO}_{2}$ nanoparticles forming photoelectrode film through electrophoretic deposition.

\section{Acknowledgements}

This work on the characterization of microstructure and the measurement of power conversion efficiency is supported by the U.S. Department of Energy, Office of Basic Energy Sciences, Division of Materials Sciences, under Award No. DE-FG02-07ER46467 (Q.F.Z.). This work is also supported in part by the National Science Foundation (DMR 1035196), the Air Force Office of Scientific Research (AFOSR-MURI, FA9550-06-1-0326), the University of Washington TGIF grant, the Royalty Research Fund (RRF-A65796) from the Office of Research at University of Washington, the Washington Research Foundation, and the Intel Corporation.

Table 1. Efficiencies and fill factors obtained from samples treated with varying post treatments after EPD.

\begin{tabular}{|c|c|c|c|}
\hline Powder & Sample Conditions & $\eta(\%)$ & FF \\
\hline \multirow{5}{*}{ P25 } & No post treatment with $450^{\circ} \mathrm{C}$ anneal & 0.95 & 0.59 \\
\hline & $1 \mathrm{~h} 0.1 \mathrm{~N} \mathrm{H}_{2} \mathrm{SO}_{4} \mathrm{H}_{2} \mathrm{O}$ Immersion followed by $15 \mathrm{~min}_{2} \mathrm{O}$ immersion with $450^{\circ} \mathrm{C}$ anneal & 3.27 & 0.56 \\
\hline & $1 \mathrm{~h} 0.1 \mathrm{~N} \mathrm{H}_{2} \mathrm{SO}_{4}$ IPA Immersion followed by $15 \mathrm{~min}$ pure IPA immersion with $450^{\circ} \mathrm{C}$ anneal & 2.65 & 0.60 \\
\hline & $15 \mathrm{~h} 0.1 \mathrm{~N} \mathrm{H}_{2} \mathrm{SO}_{4}$ IPA Immersion followed by $15 \mathrm{~min}$ pure IPA immersion with $150^{\circ} \mathrm{C}$ anneal & 1.99 & 0.68 \\
\hline & Doctor Blading & 2.94 & 0.41 \\
\hline $\mathrm{TiO}_{2}$ Nanoparticles (Lab-Made) & $15 \mathrm{~h} 0.1 \mathrm{~N} \mathrm{H}_{2} \mathrm{SO}_{4}$ IPA Immersion followed by $15 \mathrm{~min}$ pure IPA immersion & 4.91 & 0.55 \\
\hline
\end{tabular}




\section{REFERENCES}

[1] B. Oregan and M. Gratzel, "A Low-Cost, High-Efficiency Solar-Cell Based on Dye-Sensitized Colloidal $\mathrm{TiO}_{2}$ Films," Nature, Vol. 353, 1991, pp. 737-740.

doi: $10.1038 / 353737 \mathrm{a} 0$

[2] C. J. Barbe, F. Arendse, P. Comte, M. Jirousek, F. Lenzmann, V. Shklover and M. Gratzel, "Nanocrystalline Titanium Oxide Electrodes for Photovoltaic Applications," Journal of the American Ceramic Society, Vol. 80, No. 12, 1997, pp. 3157-3171. doi:10.1111/j.1151-2916.1997.tb03245.x

[3] S. Ito, T. N. Murakami, P. Comte, P. Liska, C. Gratzel, M. K. Nazeeruddin and M. Gratzel, "Fabrication of Thin Film Dye Sensitized Solar Cells with Solar to Electric Power Conversion Efficiency over 10\%," Thin Solid Films, Vol. 516, No. 4, 2008, pp. 4613-4619. doi:10.1016/j.tsf.2007.05.090

[4] D. B. Kuang, S. Ito, B. Wenger, C. Klein, J. E. Moser, R. Humphry-Baker, S. M. Zakeeruddin and M. Gratzel, "High Molar Extinction Coefficient Heteroleptic Ruthenium Complexes for Thin Film Dye-Sensitized Solar Cells," Journal of the American Chemical Society, Vol. 128, No. 12, 2006, pp. 4146-4154. doi: $10.1021 / \mathrm{ja} 058540 \mathrm{p}$

[5] T. P. Chou, Q. F. Zhang, G. E. Fryxell and G. Z. Cao, "Hierarchically Structured ZnO Film for Dye-Sensitized Solar Cells with Enhanced Energy Conversion Efficiency," Advanced Materials, Vol. 19, No. 18, 2007, pp. 2588-2592. doi:10.1002/adma.200602927

[6] Q. F. Zhang, T. R. Chou, B. Russo, S. A. Jenekhe and G. Z. Cao, "Aggregation of $\mathrm{ZnO}$ Nanocrystallites for High Conversion Efficiency in Dye-Sensitized Solar Cells," Angewandte Chemie-International Edition, Vol. 47, 2008, pp. 2402-2406. doi:10.1002/anie.200704919

[7] Q. F. Zhang, C. S. Dandeneau, X. Y. Zhou and G. Z. Cao, "ZnO Nanostructures for Dye-Sensitized Solar Cells," Advanced Materials, Vol. 21, No. 41, 2009, pp. 40874108. doi:10.1002/adma.200803827

[8] Q. F. Zhang and G. Z. Cao, "Nanostructured Photoelectrodes for Dye-Sensitized Solar Cells," Nano Today, Vol. 6, No. 1, 2011, pp. 91-109. doi:10.1016/j.nantod.2010.12.007

[9] C. Y. Jiang, X. W. Sun, K. W. Tan, G. Q. Lo, A. K. K. Kyaw and D. L. Kwong, "High-Bendability Flexible Dye-Sensitized Solar Cell with a Nanoparticle-Modified ZnO-Nanowire Electrode," Applied Physics Letters, Vol. 92, No. 14, 2008, p. 143101. doi:10.1063/1.2905271

[10] D. Kuang, J. Brillet, P. Chen, M. Takata, S. Uchida, H. Miura, K. Sumioka, S. M. Zakeeruddin and M. Gratzel, "Application of Highly Ordered $\mathrm{TiO}_{2}$ Nanotube Arrays in Flexible Dye-Sensitized Solar Cells," Acs Nano, Vol. 2, 2008, pp. 1113-1116. doi:10.1021/nn800174y
[11] K. M. Lee, S. J. Wu, C. Y. Chen, C. G. Wu, M. Ikegami, K. Miyoshi, T. Miyasaka and K. C. Ho, "Efficient and Stable Plastic Dye-Sensitized Solar Cells Based on a High Light-Harvesting Ruthenium Sensitizer," Journal of Materials Chemistry, Vol. 19, No. 28, 2009, pp. 50095015. doi:10.1039/b903852c

[12] W. W. Tan, J. M. Chen, X. W. Zhou, J. B. Zhang, Y. A. Lin, X. P. Li and X. R. Xiao, "Preparation of Nanocrystalline $\mathrm{TiO}_{2}$ Thin Film at Low Temperature and Its Application in Dye-Sensitized Solar Cell," Journal of Solid State Electrochemistry, Vol. 13, No. 5, 2009, pp. 651-656. doi:10.1007/s10008-008-0605-4

[13] H. C. Weerasinghe, P. M. Sirimanne, G. V. Franks, G. P. Simon and Y. B. Cheng, "Low Temperature Chemically Sintered Nano-Crystalline $\mathrm{TiO}_{2}$ Electrodes for Flexible Dye-Sensitized Solar Cells," Journal of Photochemistry and Photobiology A: Chemistry, Vol. 213, No. 1, 2010, pp. 30-36.

[14] J. M. Kroon, N. J. Bakker, H. J. P. Smit, P. Liska, K. R. Thampi, P. Wang, S. M. Zakeeruddin, M. Gratzel, A. Hinsch, S. Hore, U. Wurfel, R. Sastrawan, J. R. Durrant, E. Palomares, H. Pettersson, T. Gruszecki, J. Walter, K. Skupien and G. E. Tulloch, "Nanocrystalline Dye-EnsiTized Solar Cells Having Maximum Performance," Progress in Photovoltaics, Vol. 15, No. 1, 2007, pp. 1-18. doi:10.1002/pip. 707

[15] S. Nakade, M. Matsuda, S. Kambe, Y. Saito, T. Kitamura, T. Sakata, Y. Wada, H. Mori and S. Yanagida, "Dependence of $\mathrm{TiO}_{2}$ Nanoparticle Preparation Methods and Annealing Temperature on the Efficiency of Dye-Sensitized Solar Cells," Journal of Physical Chemistry B, Vol. 106, No. 39, 2002, pp. 10004-10010. doi:10.1021/jp020051d

[16] H. Chang, T. L. Chen, K. D. Huang, S. H. Chien and K. C. Hung, "Fabrication of Highly Efficient Flexible DyeSensitized Solar Cells," Journal of Alloys and Compounds, Vol. 504, No. 1001, 2010, pp. S435-S438. doi:10.1016/j.jallcom.2010.02.044

[17] C. C. Tsai, Y. Y. Chu and H. S. Teng, "A Simple Electrophoretic Deposition Method to Prepare $\mathrm{TiO}_{2}$-B Nanoribbon Thin Films for Dye-Sensitized Solar Cells," Thin Solid Films, Vol. 519, No. 2, 2010, pp. 662-665. doi:10.1016/j.tsf.2010.08.104

[18] J. H. Yum, S. S. Kim, D. Y. Kim and Y. E. Sung, "Electrophoretically Deposited $\mathrm{TiO}_{2}$ Photo-Electrodes for Use in Flexible Dye-Sensitized Solar Cells," Journal of Photochemistry and Photobiology A: Chemistry, Vol. 173, No. 1, 2005, pp. 1-6.

[19] M. J. Shane, J. B. Talbot, B. G. Kinney, E. Sluzky and K. R. Hesse, "Electrophoretic Deposition of Phosphors. 2. Deposition Experiments and Analysis," Journal of Colloid and Interface Science, Vol. 165, No. 2, 1994, pp. 334-340. doi:10.1006/jcis.1994.1237 